\title{
The Process of Financial Planning in Personal Finance
}

Dr. Sanie DODA (Corresponding author)

Lecturer, “Aleksander Moisiu” University

Durres, Albania

Email: sanijedoda@yahoo.com

Prof. Ass Dr. Shkelqim FORTUZI

Lecturer, “Aleksander Moisiu” University

Durres, Albania

Email: shkelqimfortuzi@yahoo.com

Doi:10.5296/ijhrs.v5i4.8636 URL: http://dx.doi.org/10.5296/ijhrs.v5i4.8636

\begin{abstract}
The process of financial planning is not an event separate from situations of individuals, but an evolution in predictable and unexpected situations; The planning process should take into consideration: the constant changes that occur in our lives, our resources and financial decisions.

This study claims to be a turn towards building a budget, how to save with payments, how to preserve more money for our welfare, etc. stable financial conditions. Good financial planning and maintaining financial stability will also help to prevent the financial crisis, which many cases are associated with social consequences without adjustingfor example: divorces and other consequences that distort the normal continuation of a healthy family or an individual personality unconditionally by phenomena not rationally acceptable. The financial plan of a family needs for consistency, because in this way the family will not face financial problems.Following effective management of personal income, the amount of Albanian families will be able to reach perhaps not a luxurious life, but would have a greater financial stability, more security.
\end{abstract}

Keywords: Personal finance, financial planning, budget, economy 


\section{Personal Finance}

Personal finance is the application of the principles of finance to monetary decisions an individual or family unit. This trend deals with the ways in which individuals or families obtain save budget and spend cash over time, taking into account various financial risks and future life events. (Puspa Raj Sharma, PhD Yub Raj Bohora 2010). Components of personal finance might include: checking and savings accounts, credit cards and consumer loans, investments in the stock market, retirement plans, social security benefits, insurance policies and income tax management, so all these are some of the devices leading to each member of the society is interested to learn to be aware of personal peace and security.

Such is life in a market economy, each of us is the architect of his own welfare. No one but yourself can not take care as you for your well being. To need to know how to create a personal financial plan and in countries such as ours that has passed a difficult political and economic transition, it has been a challenge without having at a financial operator in the role of counselor.Albania has not started functioning separate windows or agencies that are only in terms of personal finance. Meanwhile, Albania will see that not only banks that do not perform this role, not to make a picture of the risks or rewards that could have each individual to take up a consumer loan.

Keep in mind that money is a tool, the means by which we support our unique values and priorities. Ultimately, the richest among us are people who believe that they have enough money to live a quality life and achieve financial stability. Following a manual effective management of personal income many Albanian families could reach probably not a luxurious life, but would have a greater financial stability, more security nowadays.Financial plan requires the cost of building their wealth (Bell, M. 2005). This can not be done without a prior project. This is how the decision to build a house that without a pile of bricks and cement project is not performing work. In addition, upon approval of the project to ensure that the beam house building will not house broken and the walls will not fall. At the same form a family financial plan needs consistency (Gross, D.B., \& Souleles, N.S. 2002).Life needs a financial plan for a man of his day and the money to plan their financial future.

The cost should be to educate children?

How much money need to buy an apartment or a house forthe family?

Will we have enough money for retirement period to live comfortably in the golden season of life?

A key component of personal finance is financial planning, which is a dynamic process that requires regular monitoring and reevaluation. Below you will find a table which can help greatly in maintaining an efficient financial plan. With a few simple steps your revenue management can be significantly improved. This is because keeping a memory on what is spent or not is the first element required for a successful financial plan (Sullivan, Arthur; Steven M. Sheffrin. 2003). 


\section{Macrothink}

\section{Table 1: Revenue administration}

\section{Revenue administration: \\ In my family live together:}

increase

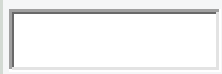

children

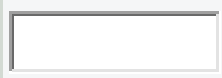

Personal monthly net income (ALL)

Net income of the spouse / as (ALL)

Other income (money)

Loan obligations (ALL)

Rent together with other costs (ALL)
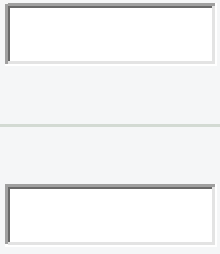

Cost of living (ALL)

Securities (ALL)

Other expenses (ALL)

\section{Result}

Source: Bank of Albania 
If you are looking for a solution to your debt problems, the most important thing is to find the right solution. Some debt solutions are suitable for large debts, others for small debts. (And "big" or "small" means different things to different people, depending on their overall financial situation). Is always available to talk to a debt adviser about your finances, but if your debts are not very serious, the best debt solution may simply be learning to budget more effectively.Everyone can be surprised how quickly you can solve the problems our debt if you really have your mind on it.

This will have little information on the balance of personal economy.As you can see, personal finances are very important to maintain the balance of our economy. Today, most Albanian families have problems with personal finances, so we have learned a few tricks that can be very useful for anyone(Elez Biberaj, 2011). The first thing to organize our personal finances is to develop very detailed monitoring of all monthly income and expenses, to know how much money you have entered and how much has been spent. Not only in this way will have detailed information which is the main source of household income.In the development of our personal finances (Fry, T.R.L., Mihajilo, S., Russell, R. and Brooks, R. 2008) we can not include money that are not recorded in our accounts. As a search mechanism and important information, is Excel program to put on a sheet of all the personal finance, information they need and can be very useful.Financial planning key step is to clearly define the goals. Once goals are set, you must set priorities and be counted timelines for achieving each goal. By this means the meetings to review plans and to ensure that needs are met.

Therefore wishes to be kept in close borders to avoid serious situation economically.Life is long and beautiful. Money is an essential component to life and so it is advisable that good management of our financial resources is one way to live a full life. Loans, budgeting, revenue collections are important components of personal financial management.Increased cost of living has become imperative that we plan and use our financial resources to our best abilities (Manski, C. 2000).

We also need to plan ahead to the best of our resources. The following are some tips that can be followed for financial planning.If we are able to keep a certain amount of money each month to the urgent need, or for our future because the time will come when there will be enough money for entertainment and leisure, and even buy a car or home. Savings during each month is an important aspect of financial discipline taught and it is an effective method for effective planning.Personal finances remain so applying finance principles for monetary decisions of an individual or family unit.

Addresses the ways in which individuals or families receiving survivors have spared budget and spend cash over time by taking into account various financial risks and future life events. Components of personal finance might include retirement plans, social security benefits, insurance policies and income tax management(Ainslie, G. 1975).

Topics in this field include the assessment of one's personal financial situation, setting goals, create a financial plan and monitoring and evaluation of the plan of someone with time. So that advice can be taken as an individual can make informed opinions to give enough information. Recognizing closer investments, bonds, mutual funds, taxes, money saving, debt 


\section{Macrothink}

management and more.

That helps a very important words in our financial lexicon: saving. See below some simple but effective tips and debt management assistance that gives savings. How much can you save at 6 months, can you try to save for such a period? 6 months is not a long time, but it may be long enough to allow us to make a serious effort to leave some "traces" in our debts, so as to make a step forward(Fry, T.R.L., Mihajilo, S., Russell, R. and Brooks, R. 2008).

The question is: How much money we spend on luxuries, money that could go to wash off your debts and how you can achieve the realization of this objective that often decide?

$>$ How much money we can save ?If we want to be more radical, try to be a little farther luxury you can afford can try cutting down to $50 \%$ of our costs substantially, resist the temptation else to spend money on things that do not need. (Just be sure not compensate this "diet" spending more on other things that we do not need and can compromise us saving method).

Advice: The best way to stay motivated is to keep a log to record any money you're saving, so you can see all those sacrifices are valid towards a road to a simpler life. In this scheme you can count the time you need to save a certain amount of money, based on a given interest. Indicate the amount of savings each year, the amount you want to save and annual interest rate. For more see table illustrated below.

Table 1.2: Calculation of the length of saving plan

The calculation of the duration of the saving plan:

Shuma vjetore e kursimeve

0

Objective

0

The annual interest rate $\%$

Duration

Source: Bank of Albania 


\section{Planning for retirement}

When we are a young age still feel vital, we think that we are just beginning to save the invests, so this question is difficult to responding with any precision. Who knows how much money we will need in retirement, when these days look like they are still far away? Now you're in your forties or fifties, it is easer to make plans this plans can be made much faster and more effectively when we still have the opportunity to work intensively to save our resources for future. Amount that will be needed depends on the age pension and salary that we have (Wilhelmson, K., Andersson, A., Waern, M. and Allebeck, P. 2005). With some simple calculations can know if you can have an easy life after retirement. And each of us knows how long it will continue to work and have an idea what to do next, a trip, to start a second career, or simply to stay. We have still time to perfect our intentions to measure our success.By my income, taking into account age at a given moment and multiplying the estimated coefficient depending on age and inflation, we can achieve required result, the amount that will finally receive at our retirement. Meanwhile in its third division notice and setting the amount of savings depending on age and salary that receives each individual. Standard financial planning advice is to give assurance that can attract up $4 \%$ of your assets in the first year of retirement (Ainslie, G. (1975). We have increased that amount each year taking into account inflation. We can use the worksheet to see where we should be up now. If we are in front or behind with our objectives than should be saving. We spend our working and taking advantage of big profits for our employer. Things are great, when we work and financial security late in life is also important and should be planned with intelligence. We need to identify our financial needs, thinking about retirement, and leaving aside some money immediately. As soon as we start the better it will be reflected in the result. Our savings should be increased gradually to support our lives after we stopped working. There are many savings schemes retirement funds available as present (Brown, S., Taylor, K., \& Price, S.W. 2005). First, we must identify the right funding scheme for yourself. We can also invest in a business that can reap rich dividends in time to retirement.

\section{Establishing a well organized wealth plan}

Good or bad, life is complicated, you can be married, with children, or divorced, you have expenses for children, health concerns. You have worked heard to protect your family, but if you die or become disable, what would happen? It depends on the management of assets. Probability this is the will that arises from age fifties, only two of three Albanians can do this. But this is only beginning. When you pass in the last update? Did you complete other essential documents that are necessary to be quiet? Probably not.You want your children to be safe, your husband/ your wife will take right care (Kwok, H., Milevsky, M., \&Robinson, C 1994). You don't want all your money to cross the second wife of your husband to abused them, because this is a overview that happens.Therefore, you must assign a babysitter for your children if they are younger than 18 years, as well as a financial custodian who will inherit money. A babysitter must be willing and able to raise your child, while the man believed to be good at managing money (Debelle, G. 2004).Implementation of the Faith. Consider the alternative to a will if you live in e a state when the courts have a slow or expensive probate. With a living trust, your estate may bypass formal verification. In most 
states, children's bank accounts opens in their name that they can use at age 18 or later. By opening the account, parents will collect or ensure that children will use the found for college and study, according to a non-convertible.

\section{Conclusions and Recommendations}

- Personal Finance address the ways in which individuals or families receive income, spend cash, save by taking into account various financial risks and future events.

- Albania has undergone a difficult political and economic transition, so has not yet started functioning separate windows or agencies that are only in terms of personal finance. This is one reason why today most Albanian families have problems with personal finances.

- Personal finance budget helps individuals understand their financial situation more clearly, and this is a very important variable to identify financial components simultaneously saving time.

- Managing family finances is not easy in the current climate. Having a family is reasonable to expect greater responsibility because not only do individuals need to take care of personal finances, but also for their family finances. Financial plan of a family needs consistency.

- Generation gap has an influence on the determination of financial planning and in determining the financial success

- Increased cost of living has made it imperative that we plan and use our financial resources effectively and efficiently.

- For a better management of household finances is recommended to open a savings account. A savings account can help many families pay for future expenses, such as tuition fees, hospital bills, and other emergencies.

\section{References}

Ainslie, G. (1975). "Specious Reward: A Behavioral /Theory of Impulsiveness and Impulse Control". Psychological Bulletin82 (4): 463-496.

Bell, M. (2005 Mar). A matter of no small interests: Real short-term interest rates and inflation since the 1990s. Speech Monetary Policy Committee (MPC) to the Institute of Directors and Milton Keynes Chambers of Commerce at Cranfield University. Bridges, S., \& Disney, R. (2004). Use of credit arrears on debt among low income families in the United Kingdom. Fiscal Studies, 25(1): 1-25.

Brown, S., Taylor, K., \& Price, S.W. (2005). Debt and distress: Evaluating the psychological cost of credit. Journal of Economic Psychology, 26: 642-3

Debelle, G. (2004 Mar). Household debt and the macroeconomy. BIS Quarterly Review, 


\section{Al Macrothink \\ International Journal of Human Resource Studies \\ ISSN 2162-3058 2015, Vol. 5, No. 4}

$51-64$.

Elez Biberaj, Shqiperia ne tranzicion -Rruga e vështirë drejt demokracisë 1990-2010, Shtëpia botuese: AiiS - Tirana Times, Viti: 2011

Fry, T.R.L., Mihajilo, S., Russell, R. and Brooks, R. 2008. The Factors Influencing Saving in a Matched Savings Program: Goals, Knowledge of Payment Instruments, and Other Behavior. Journal of Family and Economic Issues. Vol. 29, Iss. 2; faqe. 234-251.

Gross, D.B., \& Souleles, N.S. (2002). Do liquidity constraints and interest rates matter for consumer behavior? Evidence from credit card data. The Quarterly Journal of Economics, 117:149-85.

Kwok, h., Milevsky, m., \& Robinson, c. (1994). asset allocation, life expectancy, and shortfall. financial services review, 3(2):109-126.

Manski, C. (2000) IEconomic analysis of social interactions", Journal of EconomicPerspectives 14, 115-136.

Puspa Raj Sharma, PhD Yub Raj Bohora 2010, Personal Finance Knowlegde and Practice: An Opinion Survey with Employed and Self-employed People in Pokhara, The Journal of Nepalese Business Studies Vol. VII No. 1, 2010 80-85.

Sullivan, Arthur; Steven M. Sheffrin (2003). Economics: Principles in action. Upper Saddle River, New Jersey 07458: Pearson Prentice Hall. pp. 502

Wilhelmson, K., Andersson, A., Waern, M. and Allebeck, P. 2005. Elderly people's perspectives on quality of life. Ageing and Society. Vol. 25, Part 4, faqe. 585-601. 